Article

\title{
Evaluation of Olive Fruit Lipoxygenase Extraction Protocols on 9- and 13-Z,E-HPODE Formation
}

\author{
Barbara Soldo, Matilda Šprung, Gloria Mušac, Maja Pavela-Vrančić and Ivica Ljubenkov * \\ Faculty of Science, Department of Chemistry, R. Boškovića 33, Split 21 000, Croatia; barbara@pmfst.hr (B.S.); \\ msprung@pmfst.hr (M.Š.); Glo.bilic@gmail.com (G.M.); pavela@pmfst.hr (M.P.-V.) \\ * Correspondence: ivica.ljubenkov@pmfst.hr; Tel.: +385-21-385-133 \\ Academic Editor: Derek J. McPhee \\ Received: 4 March 2016; Accepted: 13 April 2016; Published: 20 April 2016
}

\begin{abstract}
In plant tissues, enzymes implicated in the lipoxygenase (LOX) pathway are responsible for the hydroperoxydation of polyunsaturated fatty acids, ultimately leading to the production of small chemical species involved in several physiological processes. During industrial olive oil production, these enzymes are activated upon crushing and grinding of olive fruit tissue, subsequently leading to the synthesis of volatile compounds responsible for the positive aroma and flavor of the oil. An investigation of LOX activity during olive fruit ripening and malaxation could assist in the production of oils with favorable aroma and taste. Therefore, a reliable method for olive LOX purification is crucial. Here we report a critical review of six LOX extraction protocols, two of which have shown minimum enzyme activity, possibly leading to misconceptions in the interpretation of experimental data. Future research concerning olive LOX should employ extraction methods that preserve enzyme activity.
\end{abstract}

Keywords: olive fruit; LOX; extraction protocols; enzyme activity; olive oil aroma

\section{Introduction}

Recent popularity of olive oil is a result of expanding interest in the Mediterranean type of diet (MedDiet) which was proved to be one of the healthiest diet types. The beneficial effect of olive oil on human health could be attributed to its chemical composition whereby monounsaturated fatty acids (MUFA) and phenolic compounds have a paramount role. Some studies have shown that MUFA may have a protective role against neurodegenerative diseases, such as age-related cognitive decline and Alzheimer's disease. In addition, phenolic compounds have antioxidant and anti-inflammatory properties which, together with volatile compounds, affect sensory attributes of olive oil [1].

Volatile compounds contributing to positive aroma perceptions of olive oil are small molecules produced by enzymes belonging to the lipoxygenase (LOX) pathway. During olive oil production, this pathway is initiated by mechanical fragmentation of olive fruit tissue, and continues during malaxation of olive paste. Enzymes belonging to the LOX pathway perform a series of reactions, during which polyunsaturated fatty acids are oxidized and cleaved, ultimately leading to the production of esters [2]. Besides the positive effect on olive oil aroma, chemical compounds released by the action of LOX enzymes are implicated in various physiological processes important for proper plant growth and development [3]. Sensory defects in olive oil aroma occur in the case of contamination by microbial enzymes or as a consequence of fatty acid autooxidation, leading to a faulty aroma and taste [2]. Proper olive fruit processing and oil storage is thus crucial for both the flavor and the overall quality of the oil produced [4].

Lypooxigenases are non-heme iron containing enzymes that catalyze the first step in the LOX pathway, namely the hydroperoxidation of polyunsaturated fatty acids [5]. Most common substrates for LOX are linoleic (LA) and linolenic acid (LnA), whereby, depending on the enzyme's 
regiospecificity, two products, $( \pm$ )9-hydroperoxy-10E,12Z-octadecadienoic acid (9-Z,E-HPOD) and $( \pm) 13$-hydroperoxy-9Z,11E-octadecadienoic acid (13-Z,E-HPOD), are formed. These products are afterwards cleaved by hydroperoxide lyase, the following enzyme in the LOX pathway, producing corresponding aldehydes, which are subsequently reduced to alcohols and esterified to esters [2].

Due to the key role that LOX has in the development of a desirable aroma in olive oils, various factors influencing enzyme activity such as variety, ripening stage and climate have been explored [2,6-14]. Results obtained in these studies have a potential application in the production of oils with favorable green and fruity sensory notes [7]. In order to characterize factors influencing LOX activity, an extraction procedure that preserves enzyme activity is of fundamental importance for experimental data collection and interpretation. Here we report an analysis of six protocols for LOX isolation and the effect that these procedures have on product formation, 9- and 13-hydroperoxy fatty acid.

\section{Results and Discussion}

\subsection{Determination of LOX Activity}

Despite numerous data available for plant LOXs, information about olive LOX is scarce due to difficulties in enzyme purification [11]. These difficulties could be explained by a high concentration of phenols in the olive fruit, which can react with proteins, changing their properties and affecting their solubility. Moreover, hydrophobicity of LOX may cause protein aggregation, making the extraction process even more demanding [7]. Nonetheless, several research groups have successfully isolated olive LOX utilizing various modified procedures, independently described by Georgalaki and Donaire $[15,16]$. The purpose of this study was to determine the extent to which those extraction procedures affect enzyme activity. This information could be valuable to researchers interested in improving olive oil aroma by correlating different factors, such as ripening stage, variety and climate, influencing LOX enzyme activity.

The LOX extraction process was performed according to previously published procedures [6-8,12-14], and the total protein concentration was determined by the Bradford method using bovine serum albumin (BSA) as standard (Table 1).

Table 1. Total protein concentration measured by the Bradford method using bovine serum albumin (BSA) as standard.

\begin{tabular}{cccc}
\hline Reference & Protocol & Fraction & Protein Concentration/ $\mathbf{\mu g} \cdot \mathbf{~ m L}^{-\mathbf{1}}$ \\
\hline$[8]$ & 1 & & $1044.40 \pm 23.04$ \\
{$[6]$} & 2 & & $1026.15 \pm 37.43$ \\
{$[7]$} & 3 & & $548.72 \pm 20.05$ \\
{$[14]$} & 4 & & \\
& & A & $1508.69 \pm 45.01$ \\
& & B & $340.12 \pm 25.64$ \\
& & $\mathrm{C}$ & $896.60 \pm 5.96$ \\
{$[13]$} & 5 & $\mathrm{D}$ & $1190.45 \pm 50.66$ \\
{$[12]$} & 6 & & $970.78 \pm 37.18$ \\
\hline
\end{tabular}

The total amount of isolated protein ranged between $200-1600 \mu \mathrm{g} \cdot \mathrm{mL}^{-1}$. The lowest protein concentration was obtained from the heavy membrane (4B) and microsomal fractions (4D) using protocol 4.

In order to estimate the effect of the LOX extraction procedure on enzyme activity, the concentration of 9-Z,E-HPODE and 13-Z,E-HPODE, following a 30-min incubation period, was determined by RP-HPLC. The results depicted in Figure 1A,B represent the average amount of reaction products from three independent measurements. 


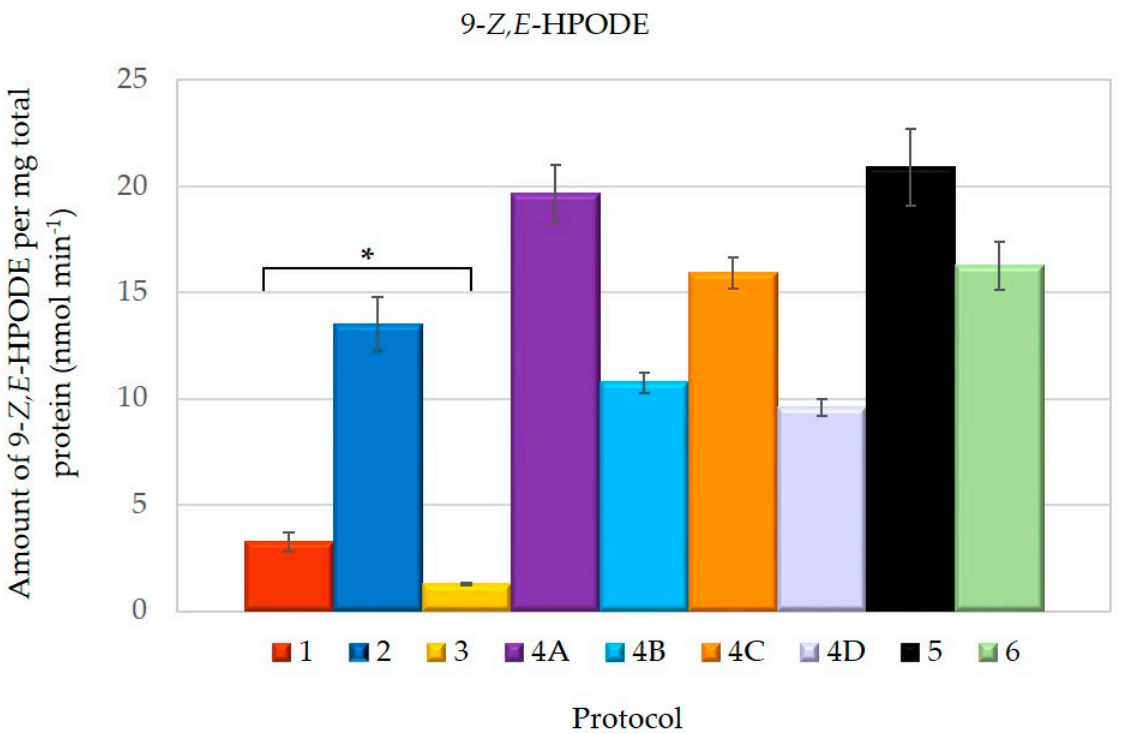

(A)

13-Z,E-HPODE

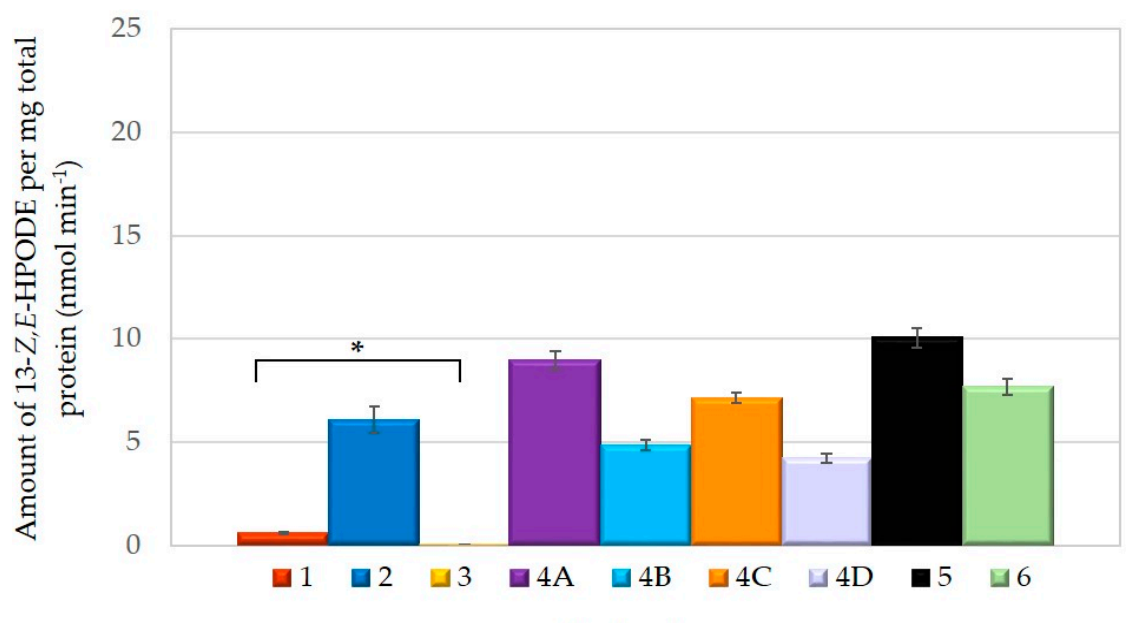

Protocol

(B)

Figure 1. Lipoxygenase (LOX) activity calculated from the amount of: (A) $9-Z, E-H P O D E$ and (B) 13-Z,E-HPODE, as determined by RP-HPLC with depicted bars representing * $p<<0.05$ (Anova, single factor and Scheffe test).

LOX activity, determined in our study is lower then in the original papers. This can be attributed to the variability of Croatian indigenous olive cultivar or to different olive fruit ripening stages. Additionally, our results clearly indicate that LOX predominantly produces 9-Z,E-HPODE, which is almost two times more abundant than 13-Z,E-HPODE (Table 2). This HPODE ratio was previously reported by Palmieri-Thiers et al. [17].

Table 2. 9- and 13-HPODE ratio in tested protocols.

\begin{tabular}{cccccccccc}
\hline Protocol & $\mathbf{1}$ & $\mathbf{2}$ & $\mathbf{3}$ & $\mathbf{4 A}$ & $\mathbf{4 B}$ & $\mathbf{4 C}$ & $\mathbf{4 D}$ & $\mathbf{5}$ & $\mathbf{6}$ \\
\hline 9-/13-Z,E-HPODE & 5.47 & 2.22 & 49.85 & 2.19 & 2.21 & 2.23 & 2.26 & 2.08 & 2.12 \\
\hline
\end{tabular}

However, the most striking observation was the reduced amount of both products synthesized by LOX when using protocol 1 and 3. Although LOX extracted using protocol 1 appeared to be 
more active than the one obtained by protocol 3, both resulted in a significantly lower product yield compared to other tested procedures. For comparison, chromatograms of LOX product formation, following protocol 1, 3 and 5, displaying the lowest and highest enzyme activity, are represented in Figure 2.

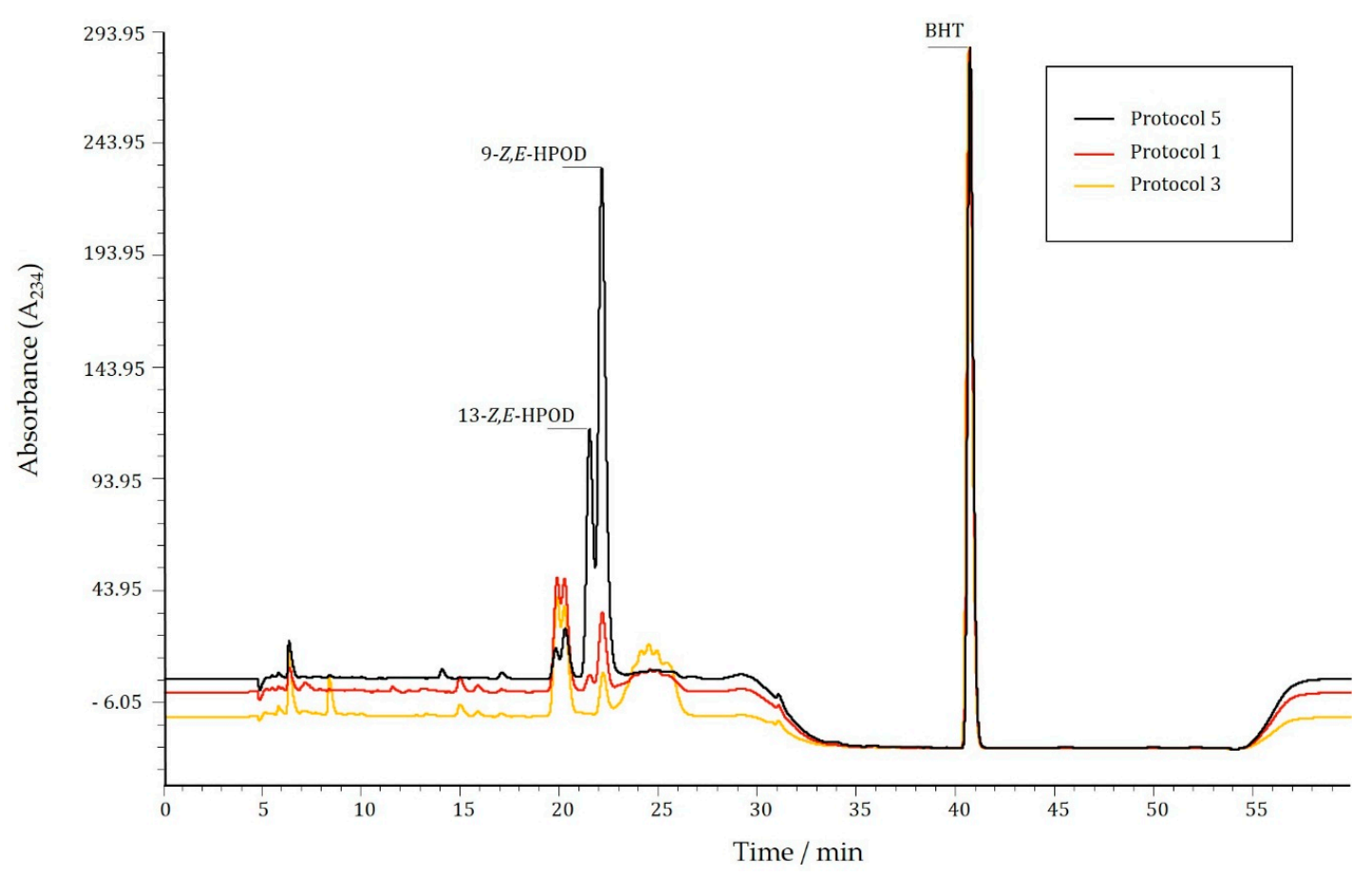

Figure 2. Overlaid representation of chromatograms of LOX product formation obtained by applying protocol 1,3 and 5 .

One reason for this could be the amount of polyvinyl polypyrrolidone (PVPP), which in protocol 1 and 3 , is less than $5 \%(w / v)$, compared to protocol 5 where $10 \%(w / v)$ of PVPP is used. The role of PVPP is to neutralize phenols, which otherwise inhibit LOX, consequently leading to lower enzyme activity [18], as shown with soybean lipoxygenase, proven to be inhibited by lipophylic- and hydrophylic phenolic compounds [19]. In addition, protocol 1 and 3 omitted phenylmethylsulfonyl fluoride (PMSF), an inhibitor of serine proteases. Once released, proteases could degrade LOX, contributing to lower enzyme activity encountered in LOX samples obtained applying these protocols. Protocol 6 also omits the use of PMSF but, on the contrary, has higher LOX activity most probably due to ammonium-sulphate precipitation [20].

When product formation by LOX obtained using protocol 1 and 3 was determined spectrophotometrically, it displayed, respectively, an almost 20 and 100 times higher value then the one detected by RP-HPLC (Table 3). In contrast, the level of product formation obtained using protocol 5 displayed the same value irrespective of the method. Samples extracted by protocol 1 and 3 contain impurities that could give false positive spectrophotometric measurements. Impurities can be seen in chromatograms shown in Figure 2, as a broad peak following the signal for 9-Z,E-HPODE in both sample 1 and 3 . When shorter incubation period was tested $(5 \mathrm{~min})$, the same amount of impurities were noticed, implying that, most likely, this band is not a result of enzyme byproduct, but rather some impurity that retarded during the isolation process. Both methods, RP-HPLC and spectrophotometry, detect reaction products at a wavelength of $234 \mathrm{~nm}\left(\mathrm{~A}_{234}\right)$, where other chemical species with conjugated double bonds could also absorb.

Taking into account our results, it is evident that two of the reported enzyme isolation procedures are not a suitable choice for LOX investigation. These protocols result in protein extracts that contain a lower amount of desirable reaction products. Therefore, if protocols 1 and 3 are to be used, 
spectrophotometry has to be complemented by RP-HPLC analysis in order to avoid false results regarding the level of 9-Z,E-HPODE and 13-Z,E-HPODE production. This, in turn, should help in bringing accurate conclusions about factors influencing 9-Z,E-HPODE and 13-Z,E-HPODE synthesis, with potential application in the production of oils with a favorable aroma and taste.

Table 3. LOX specific activity determined by RP-HPLC and spectrophotometrically at $27^{\circ} \mathrm{C}$. The results represent an average from three independent measurements. The significantly lower amount of the reaction products is depicted with $* x<0.05$ (Anova single factor and Scheffe test).

\begin{tabular}{|c|c|c|c|c|}
\hline \multirow[b]{2}{*}{ Reference } & \multirow{3}{*}{ Protocol } & \multicolumn{2}{|c|}{ RP-HPLC } & \multirow{2}{*}{$\begin{array}{c}\text { Spectrophotometry } \\
\text { Amount of Product Per } \mathrm{mg} \text { of } \\
\text { Total Protein }\left(\mathrm{nmol} \cdot \mathrm{min}^{-1}\right)\end{array}$} \\
\hline & & \multicolumn{2}{|c|}{$\begin{array}{l}\text { Amount of Product Per mg of } \\
\text { Total Protein }\left(\mathrm{nmol} \cdot \mathrm{min}^{-1}\right)\end{array}$} & \\
\hline & & 9-Z,E-HPODE & 13-Z,E-HPODE & \\
\hline [8] & 1 & $3.23 \pm 0.44 *$ & $0.59 \pm 0.04 *$ & $84.08 \pm 1.11$ \\
\hline [7] & 3 & $1.29 \pm 0.06^{*}$ & $0.03 \pm 0.003 *$ & $121.12 \pm 3.50$ \\
\hline [13] & 5 & $20.89 \pm 1.82$ & $10.05 \pm 0.49$ & $37.17 \pm 0.56$ \\
\hline
\end{tabular}

\section{Materials and Methods}

\subsection{Materials}

9-Z,E- and 13-Z,E-hydroperoxides were purchased from Cayman Chemical (Cayman Europe, Tallinn, Estonia). Linoleic acid (LA), butylhydroxytoluene (BHT) and all other chemicals used in this study were obtained from Sigma-Aldrich (Sigma-Aldrich, Taufkirchen, Germany).

\subsection{Plant Material}

Fruits from Olea europea L. "Oblica" cultivar were sampled from a nearby olive-grove in Kaštela, Croatia, positioned at $43^{\circ} 33^{\prime} 40.3^{\prime \prime} \mathrm{N} ; 16^{\circ} 22^{\prime} 23.3^{\prime \prime} \mathrm{E}$. The fruits were handpicked in a random manner, comprising the whole perimeter of the tree at different heights and depths of the branches. The ripeness index (RI) was determined evaluating the parameters described by Uceda et al. and calculated to be 2.07 [21]. Upon picking, samples were immediately stored at $-80^{\circ} \mathrm{C}$.

\subsection{Protein Extraction Procedures}

LOX extraction was performed according to previously published protocols [6-8,12-14]. Olive fruits were weighted, and the olive pulp was homogenized in an extraction buffer during 4 cycles of $30 \mathrm{~s}$, with a $1 \mathrm{~min}$ pause, on ice at 15,000 rpm's with Polytron PT 1600 E (Kinematica, Eschbach, Germany). The homogenizate was filtered through one layer of Miracloth (Millipore, Darmstadt, Germany) and centrifuged (Table 4).

Protocols 1 and 3 complete the extraction process by the centrifugation step depicted in Table 4 . Protocol 5 includes an additional centrifugation step at $10,000 \times g$, for $10 \mathrm{~min}$ at $4{ }^{\circ} \mathrm{C}$. In each case, the obtained pellets are discarded and supernatants, containing LOX, are further used for the enzyme activity assay. In protocol 2 the pellet is retained and resuspended in $25 \mathrm{mM}$ HEPES buffer ( $\mathrm{pH} 7.5$ ) containing $10 \%$ glycerol $(v / v)$. Protocol 6 is the only protocol where proteins from the supernatant were precipitated with $75 \%$ ammonium sulphate $(w / v)$ and obtained by centrifugation at $20,000 \times g$, for $90 \mathrm{~min}$. Protein pellets were further resuspended in $50 \mathrm{mM}$ sodium phosphate buffer ( $\mathrm{pH}$ 6.8) and dialyzed overnight.

Differential centrifugation was carried out only in protocol 4 . The filtered homogenizate was first centrifuged at $1000 \times g$ for $5 \mathrm{~min}$, then at $28,000 \times g$ for $12 \mathrm{~min}$, and finally at $100,000 \times g$ for one hour at $4{ }^{\circ} \mathrm{C}$. Only the pellet from the first centrifugation step $(1000 \times g)$ was discarded. Pellets (resuspended in $20 \mathrm{mM}$ Tris buffer, $\mathrm{pH} 7.5$ containing $10 \mathrm{mM}$ histidine) and supernatants from other centrifugation steps $(28,000$ and $100,000 \times g)$ were further used for enzyme activity measurements. The concentration of all protein extracts was determined by the Bradford method [22]. 
Table 4. Description of protein extraction procedures.

\begin{tabular}{|c|c|c|c|c|c|c|}
\hline Protocol & 1 & 2 & 3 & 4 & 5 & 6 \\
\hline Ref & {$[8]$} & {$[6]$} & [7] & [14] & {$[13]$} & {$[12]$} \\
\hline Olive pulp mass (g) & 10 & 10 & 10 & 15 & 10 & 10 \\
\hline Volume of Extraction buffer (mL) & 40 & 50 & 50 & 90 & 40 & 40 \\
\hline Extraction buffer composition & $\begin{array}{c}50 \mathrm{mM} \mathrm{Na}_{2} \mathrm{PO}_{4} \\
\text { buffer, pH } 6.8 \\
0.2 \mathrm{mM} \text { EDTA } \\
0.3 \mathrm{mM} \text { DTT } \\
1 \mathrm{~g} \text { PVPP } \\
(2 \% \text { w } / v) \\
0.2 \% \text { Triton X-100 } \\
/ \\
10 \mathrm{mM} \mathrm{Na}_{2} \mathrm{~S}_{2} \mathrm{O}_{7} \\
/ \\
/ \\
/ \\
/ \\
/ \\
/ \\
/ \\
/\end{array}$ & $\begin{array}{c}50 \mathrm{mM} \text { HEPES } \\
\text { pH } 7.5 \\
5 \mathrm{mM} \text { EDTA } \\
3 \mathrm{mM} \text { DTT } \\
5 \mathrm{~g} \text { PVPP } \\
(\mathbf{1 0} \% \text { w } / v) \\
/ \\
20 \mathrm{mM} \mathrm{KCl} \\
/ \\
2 \mathrm{mM} \mathrm{MgCl} \\
7 \mathrm{mM} \beta-\mathrm{ME} \\
0.1 \% \text { ascorbate } \\
10 \% \text { glycerol } \\
330 \mathrm{mM} \text { sorbitol } \\
/ \\
/ \\
/\end{array}$ & $\begin{array}{c}50 \mathrm{mM} \mathrm{Na}_{2} \mathrm{PO}_{4} \text { buffer, } \\
\mathrm{pH} 6.8 \\
5 \mathrm{mM} \text { EDTA } \\
3 \mathrm{mM} \mathrm{DTT} \\
1 \mathrm{~g} \text { PVPP } \\
(2 \% w / v) \\
0.12 \% \mathrm{Triton} \mathrm{X}-100 \\
20 \mathrm{mM} \mathrm{KCl} \\
10 \mathrm{mM} \mathrm{Na}_{2} \mathrm{~S}_{2} \mathrm{O}_{7} \\
/ \\
/ \\
/ \\
/ \\
/ \\
/ \\
/ \\
/\end{array}$ & $\begin{array}{c}50 \mathrm{mM} \text { HEPES/KOH, } \\
\text { pH } 7.5 \\
5 \mathrm{mM} \text { EDTA } \\
3 \mathrm{mM} \text { DTT } \\
4.5 \mathrm{~g} \text { PVPP } \\
(5 \% w / v) \\
/ \\
20 \mathrm{mM} \mathrm{KCl} \\
/ \\
2 \mathrm{mM} \mathrm{MgCl} 2 \\
7 \mathrm{mM} \beta-\mathrm{ME} \\
0.1 \% \text { ascorbate } \\
10 \% \text { glycerol } \\
/ \\
10 \mathrm{mM} \text { His } \\
0.25 \mathrm{M} \text { sucrose } \\
0.1 \mathrm{mM} \text { PMSF } \\
0.1 \mathrm{mM} \text { benzamidine } \\
5 \text { mM } \\
\alpha \text {-aminocaprioic acid }\end{array}$ & $\begin{array}{c}100 \mathrm{mM} \mathrm{Na}_{2} \mathrm{PO}_{4} \\
\text { buffer, pH } 6.7 \\
1 \mathrm{mM} \text { EDTA } \\
/ \\
2 \mathrm{~g} \mathrm{PVPP} \\
(5 \% \text { w } / v) \\
0.1 \% \text { Triton X-100 } \\
/ \\
/ \\
/ \\
/ \\
/ \\
/ \\
/ \\
0.1 \mathrm{mM} \text { PMSF } \\
/ \\
5 \text { mM } \\
\alpha \text {-aminocaprioic acid }\end{array}$ & $\begin{array}{c}50 \mathrm{mM} \mathrm{Na}{ }_{2} \mathrm{PO}_{4} \\
\text { buffer, } \mathrm{pH} 6.8 \\
0.2 \mathrm{mM} \text { EDTA } \\
0.3 \mathrm{mM} \mathrm{DTT} \\
5 \mathrm{~g} \text { PVPP } \\
(\mathbf{1 2 . 5} \% \mathrm{w} / \mathrm{v}) \\
0.1 \% \text { Triton X-100 } \\
/ \\
10 \mathrm{mM} \mathrm{Na} \mathrm{S}_{2} \mathrm{O}_{7} \\
/ \\
/ \\
/ \\
/ \\
/ \\
/ \\
/ \\
/ \\
/\end{array}$ \\
\hline Homogenization & \multicolumn{6}{|c|}{4 cycles, $30 \mathrm{~s}$ and $1 \mathrm{~min}$ of pause at $4^{\circ} \mathrm{C}$} \\
\hline Centrifugation & $\begin{array}{c}10,000 \times g, 10 \mathrm{~min}, \\
4{ }^{\circ} \mathrm{C}\end{array}$ & $\begin{array}{c}40,000 \times g, 20 \mathrm{~min}, \\
4{ }^{\circ} \mathrm{C}\end{array}$ & $\begin{array}{c}13,000 \times g, 20 \mathrm{~min}, \\
4{ }^{\circ} \mathrm{C}\end{array}$ & Differential & $\begin{array}{c}27,000 \times g, 20 \mathrm{~min} \\
4{ }^{\circ} \mathrm{C}\end{array}$ & $\begin{array}{c}27,000 \times g, 30 \mathrm{~min} \\
4{ }^{\circ} \mathrm{C}\end{array}$ \\
\hline
\end{tabular}




\subsection{Preparation of Linoleic Acid Emulsion}

Linoleic acid (LA) was prepared following the method described by Axelrod et al. [23]. LA $(25 \mathrm{mM})$ was emulgated in a water containing $1.28 \%$ Tween-20 and $30 \mathrm{mM} \mathrm{NaOH}$. In order to eliminate dissolved oxygen, water was previously treated under nitrogen flow.

\subsection{Determination of LOX Activity}

\subsubsection{Synthesis and Extraction of Hydroperoxides}

Synthesis and extraction of hydroperoxides was performed by modification of previously published procedure [14]. The enzyme mixture $(2.5 \mathrm{~mL})$ containing $0.1 \mathrm{M}$ MES buffer ( $\mathrm{pH} 6.0)$, protein extract $\left(100 \mu \mathrm{g} \cdot \mathrm{mL}^{-1}\right)$ and linoleic acid $(250 \mu \mathrm{m})$ was stirred for $30 \mathrm{~min}$ at $27^{\circ} \mathrm{C}$. The reaction was stopped by addition of $\mathrm{HCl}(1 \mathrm{M})$ to $\mathrm{pH}$ 2. The reaction products, 9-Z,E-HPOD and 13-Z,E-HPOD, were extracted in three successive steps, first two with $5 \mathrm{~mL}$ and the last one with $2.5 \mathrm{~mL}$ of a hexane:isopropanol solution $(95: 5 \mathrm{v} / \mathrm{v})$. In addition, the extraction solution contained BHT antioxidant $(0.22 \mathrm{mM})$ as an internal standard that absorbs at the detection wavelength of $234 \mathrm{~nm}$, and does not interfere with LOX reaction products. Pooled extracts were further evaporated under nitrogen flow and resuspended in 200-600 $\mu \mathrm{L}$ of an acetonitrile:water mixture $(67: 33 v / v)$.

\subsubsection{RP-HPLC Analysis}

RP-HPLC analysis was performed following slightly modified procedure described by Patui et al. [14]. The reaction products were separated by RP-HPLC (Perkin Elmer Series 200, Perkin Elmer, Waltham, MA, USA) on two Zorbax Eclipse XDB-C18 columns ( $5 \mu \mathrm{m}, 4.6 \mathrm{~mm} \times 250 \mathrm{~mm}$ and $5 \mu \mathrm{m}, 4.6 \mathrm{~mm} \times 150 \mathrm{~mm}$, Agilent, Santa Clara, CA, USA) connected in series, using $0.25 \%$ acetic acid as solvent $\mathrm{A}$ and acetonitrile as solvent $\mathrm{B}$, at $35^{\circ} \mathrm{C}$. After injecting $10 \mu \mathrm{L}$ of sample, the following instrument set up parameters were applied: 0-22 min 37\% solvent A, 63\% solvent B; $22-47 \mathrm{~min} 20 \%$ solvent A, $80 \%$ solvent B; $47-60 \mathrm{~min} 37 \%$ solvent $A$ and $80 \%$ solvent $B$ at a flow rate of $0.8 \mathrm{~mL} \cdot \mathrm{min}^{-1}$. LOX reaction products were detected at $234 \mathrm{~nm}$ by a UV-Vis detector (Perkin Elmer Series 200) and quantified using calibration curves of pure standards. The calibration range was $0.5-64.87 \mu \mathrm{g} \cdot \mathrm{mL}^{-1}$ of for $( \pm) 9-Z, E-H P O D$ and $0.25-35.14 \mu \mathrm{g} \cdot \mathrm{mL}^{-1}$ of for $( \pm) 13-Z, E-H P O D$, with $R^{2} 0.9991$ and 0.9999, respectively. Limit of detection (LOD) and limit of quantification (LOQ) for each of the reaction products is given in Table 5 below:

Table 5. Limits of detection (LOD) and quatification (LOQ) for 9-Z,E-HPODE and 13-Z,E-HPODE.

\begin{tabular}{ccc}
\hline Limits of Detection and Quantifiction & 9-Z,E-HPOD & 13-Z,E-HPOD \\
\hline LOD & 0.016 & 0.017 \\
LOQ & 0.047 & 0.050 \\
\hline
\end{tabular}

\subsubsection{Spectrophotometric Analysis}

LOX activity was measured spectrophotometrically (Perkin Elmer Lambda Bio 40) at $27^{\circ} \mathrm{C}$ as described in [6-8,12-14]. The increase in absorbance was recorded for $5 \mathrm{~min}$ and the formation of reaction products was detected at $234 \mathrm{~nm}$. The reaction mixture $(1 \mathrm{~mL})$ contained $0.1 \mathrm{M}$ MES buffer $(\mathrm{pH} 6.0)$, linoleic acid $(250 \mu \mathrm{m})$ and protein extract $\left(5 \mu \mathrm{g} \cdot \mathrm{mL}^{-1}\right)$.

\subsection{Statistical Analysis}

Microsoft Excel ANOVA single factor tool was used for the analysis of 9- and 13-Z,E-HPODE amount in all six tested protocols. In order to identify LOX extraction protocols that show the greatest difference in mean values. The Scheffe test was additionally performed. 


\section{Conclusions}

The present study explores the effect of six previously reported olive LOX extraction protocols on 9- and 13-Z,E-HPODE formation. Our results point at a significantly lower amount of both HPODE products in LOX protein extracts prepared according to protocols 1 and 3. Not only does LOX prepared by these protocols have low product yield, but it also contains impurities that could interfere with spectrophotometric measurements. Therefore, if detection of olive LOX HPODE products is determined at $234 \mathrm{~nm}$ by spectrophotometry, confirmation by other selective methods, like RP-HPLC, is recommended. Otherwise, spectrophotometric measurements could lead to misinterpretation of LOX activity data.

Acknowledgments: This work was supported by the Croatian Ministry of Science, Education and Sports as part of Multiannual Financing intended for institutions, Splitsko-Dalmatinska County and CEMEX Croatia dd. The authors would like to thank Lucija Krce for her assistance in statistical analyisis.

Author Contributions: B.S. and I.L.J. conceived and designed the experiments; B.S. and G.M. performed the experiments; B.S. and M.Š. analyzed the data; M.P.V. contributed to the discussion; M.Š. wrote the paper. All authors read and approved the final manuscript.

Conflicts of Interest: The authors declare no conflict of interest.

\section{Abbreviations}

The following abbreviations are used in this manuscript:

$\begin{array}{ll}\text { LOX } & \text { Lipoxygenase } \\ \text { LA } & \text { Linoleic acid } \\ \text { LnA } & \text { Linolenic acid } \\ \text { 9-E,Z-HPOD } & ( \pm) \text { 9-hydroperoxy-10E,12Z-octadecadienoic acid } \\ \text { 13-Z,E-HPOD } & ( \pm) \text { 13-hydroperoxy-9Z,11E-octadecadienoic acid } \\ \text { BSA } & \text { Bovine serum albumin } \\ \text { RP-HPLC } & \text { reverse-phase high pressure liquid chromatography } \\ \text { PVPP } & \text { Polyvinyl polypyrrolidone } \\ \text { PMSF } & \text { Phenylmethylsulfonyl fluoride } \\ \text { HEPES } & \text { 4-(2-hydroxyethyl)-1-piperazineethanesulfonic acid } \\ \text { MES } & \text { 2-(N-morpholino)ethanesulfonic acid } \\ \text { BHT } & \text { Butylated hydroxytoluene } \\ \mathrm{A}_{234} & \text { Absorbance at 234 nm }\end{array}$

\section{References}

1. López-Miranda, J.; Pérez-Jiménez, F.; Ros, E.; de Caterina, R.; Badimón, L.; Covas, M.I.; Escrich, E.; Ordovás, J.M.; Soriguer, F.; Abiá, R.; et al. Olive oil and health: Summary of the II international conference on olive oil and health consensus report, Jaén and Córdoba (Spain) 2008. Nutr. Metab. Cardiovasc. Dis. 2010, 20, 284-294. [CrossRef] [PubMed]

2. Kalua, C.M.; Allen, M.S.; Bedgood, D.R.; Bishop, A.G.; Prenzler, P.D.; Robards, K. Olive oil volatile compounds, flavour development and quality: A critical review. Food Chem. 2007, 100, 273-286. [CrossRef]

3. Porta, H.; Rocha-Sosa, M. Update on Plant Lipoxygenases Plant Lipoxygenases. Physiological and Molecular Features. Plant Physiol. 2002, 130, 15-21. [CrossRef] [PubMed]

4. Bubola, I.B.; Koprivnjak, K.; Belobrajić, O.S.B. Influence of storage temperature on quality parameters, phenols and volatile compounds of Croatian virgin olive oils. Grasas Aceites 2014, 65. [CrossRef]

5. Brash, A.R. Lipoxygenases: Occurence, Functions, Catalysis, and Acquisition of Substrate. J. Biol. Chem. 1999, 274, 23679-23683. [CrossRef] [PubMed]

6. Salas, J.J.; Williams, M.; Harwood, J.L.; Sánchez, J. Lipoxygenase Activity in Olive (Olea europaea) Fruit. J. Am. Oil Chem. Soc. 1999, 76, 1163-1999. [CrossRef] 
7. Kotti, F.; Jaziri, K.; Arab, F.; Mater, Y.; Sifi, S.; Fares, N.; Hammami, M.; Gargouri, M. Lipoxygenase: Optimization of Extraction and Evaluation of its Contribution to Virgin Olive Oil Aroma. Food Biotechnol. 2010, 24, 95-105. [CrossRef]

8. Gallardo-Guerrero, L.; Jaren-Galan, M.; Hornero-Mendez, D.; Minguez-Mosquera, M.I. Evidence for the involvement of lipoxygenase in the oxidative processes associated with the appearance of green staining alteration in the Gordal olive. J. Sci. Food Agric. 2003, 83, 1487-1492. [CrossRef]

9. Gregorio, A.; Dugo, G. Lipoxygenase activities in ripening olive fruit tissue. J. Food Biochem. 2000, 24, 417-426. [CrossRef]

10. Dhifi, W.; Angerosa, F.; Serraiocco, A.; Oumar, I.; Hamrouni, I.; Marzouk, B. Virgin olive oil aroma: Characterization of some Tunisian cultivars. Food Chem. 2005, 93, 697-701. [CrossRef]

11. Maury, J.; Palmieri-Thiers, C.; de Caraffa, V.B.-B.; Lorenzi, V.; Gambotti, C.; Giannettini, J.; Berti, L. Biochemical and molecular aspects of olive lipoxygenase. In Advances in Olive Resource; Berti, L., Maury, J., Eds.; Transworld Research Network: Kerala, India, 2009.

12. Ridolfi, M.; Terenziani, S.; Patumi, M.; Fontanazza, G. Characterization of the lipoxygenases in some olive cultivars and determination of their role in volatile compounds formation. J. Agric. Food Chem. 2002, 50, 835-839. [CrossRef] [PubMed]

13. Luaces, P.; Sanz, C.; Pérez, A.G. Thermal stability of lipoxygenase and hydroperoxide lyase from olive fruit and repercussion on olive oil aroma biosynthesis. J. Agric. Food Chem. 2007, 55, 6309-6313. [CrossRef] [PubMed]

14. Patui, S.; Braidot, E.; Peresson, C.; Tubaro, F.; Mizzau, M.; Rabiei, Z.; Conte, L.; Macrì, F.; Vianello, A. Lipoxygenase and hydroperoxide lyase activities in two olive varieties from Northern Italy. Eur. J. Lipid Sci. Technol. 2010, 112, 780-790. [CrossRef]

15. Donaire, J.; Belver, A.; Rodriguez-Garcia, M.; Megias, L. Lipid biosynthesis, oxidative enzyme activities and cellular changes in growing olive fruit. Rev. Esp. Fisiol. 1984, 40, 191-203. [PubMed]

16. Georgalaki, M.D.; Bachmann, A.; Sotiroudis, T.G.; Xenakis, A.; Porzel, A.; Feussner, I. Characterization of a 13-lipoxygenase from virgin olive oil and oil bodies of olive endosperms. Lipid Fett 1998, 100, 554-560. [CrossRef]

17. Palmieri-Thiers, C.; Canaan, S.; Brunini, V.; Lorenzi, V.; Tomi, F.; Desseyn, J.-L.; Garscha, U.; Oliw, E.H.; Berti, L.; Maury, J. A lipoxygenase with dual positional specificity is expressed in olives (Olea europaea L.) during ripening. Biochim. Biophys. Acta 2009, 1791, 339-346. [CrossRef] [PubMed]

18. Charmont, S.; Jamet, E.; Pont-Lezica, R.; Canut, H. Proteomic analysis of secreted proteins from Arabidopsis thaliana seedlings: Improved recovery following removal of phenolic compounds. Phytochemistry 2005, 66, 453-461. [CrossRef] [PubMed]

19. Kubicka, E.; Jçdrychowski, L.; Amarowicz, R. Effect of phenolic compounds extracted from sunflower seeds on native lipoxygenase activity. Grassas Y Aceties 1999, 50, 127-130. [CrossRef]

20. Zhang, S.; Zhang, L.-L.; Zhou, K.-K.; Liu, Y.-J.; Zhao, Z. Evaluation of three types of protein extraction methods for tetraploid black locust (Robinia pseudoacacia L.) phloem tissue proteome analysis by two-dimensional electrophoresis. Anal. Methods 2015, 7, 1008-1017. [CrossRef]

21. Uceda, M.; Frias, L. Trend of the quality and quantitative composition of olive fruit oil during ripening. In Proceedings of the International Meeting on Olive Oil, Cordoba, Spain, 1975; pp. 25-46.

22. Bradford, M.M. A rapid and sensitive method for the quantitation of microgram quantities of protein utilizing the principle of protein-dye binding. Anal. Biochem. 1976, 72, 248-254. [CrossRef]

23. Axelrod, S.; Cheesbrough, B.; Laakso, M. Lipooxygenase from Soybeans. Methods Enzymol. 1981, 71, $441-451$.

Sample Availability: Plant samples are available from the authors. 